\title{
Ykamyabas: poéticas de um corpo-território
}

\author{
Ykamyabas: Poetics of a Body-Territory
}

Ykamyabas: poéticas de un cuerpo-territorio

Renata Aguiar (Universidade Federal do Rio de Janeiro, Brasil)*

https://doi.org/10.22409/poiesis.v22i37.47234

\begin{abstract}
RESUMO: O presente artigo percorre o corpo-território de rios e terras de uma Amazônia vivida e imaginada, lugar de origem e afeto que, contando as histórias das Ykamyabas - tribo de mulheres sem maridos que viviam na região do baixo amazonas -, colhe os vestígios deixados por seu imaginário mítico na relação arquetípica da mulher selvagem em narrativas que chegam principalmente pela oralidade, de modos de vida que subvertem a cisão do mundo operada pelos dualismos cultura/natureza, masculino/feminino, corpo/mente. Para articular cenas e, a partir da fotografia, reconstruir realidades, num conhecimento revelado pelo fato mítico do sonho, do fazer-se artista, da subjetividade investida de corpo, plantando pistas para outros mundos possíveis.
\end{abstract}

PALAVRAS-CHAVE: Ykamyabas; Amazônia; imaginário; feminino; mito

\footnotetext{
* Renata Aguiar é Doutoranda no Programa de Pós-Graduação em Artes Visuais da Escola de Belas Artes da Universidade Federal do Rio de Janeiro. Orcid: https:// orcid.org/0000-0001-8422-3065. E-mail: criativarenta@gmail.com.
} 
ABSTRACT: This article travels through the rivers and lands of a territorial body in to a lived and imagined Amazon, a place of origin and affection that, telling the stories of the Ykamyabas - a tribe of women without husbands who lived in the lower Amazon river region -, gather the traces left for their mythical imagery in the archetypal relationship of the wild woman in narratives that come mainly through orality, from ways of life that subvert the split of the world operated by the dualisms culture/nature, male/female, body/mind. To articulate scenes and, through photography, reconstruct realities, in a knowledge revealed by the mythical fact of the dream, of becoming an artist, of the subjectivity invested with the body, planting clues to other possible worlds.

KEYWORDS: Ykamyabas; Amazon; imaginary; feminine; myth

RESUMEN: Este artículo viaja a través del territorio corporal de ríos y tierras de una Amazonía vivida e imaginada, un lugar de origen y afecto que, contando las historias de los Ykamyabas, una tribu de mujeres sin maridos que vivían en la región amazónica inferior, cosecha los rastros que quedan por sus imágenes míticas en la relación arquetípica de la mujer salvaje en narraciones que provienen principalmente de la oralidad, de formas de vida que subvierten la división del mundo operado por los dualismos cultura / naturaleza, hombre / mujer, cuerpo / mente. Articular escenas $y$, desde la fotografía, reconstruir realidades, en un conocimiento revelado por el hecho mítico del sueño, de convertirse en artista, de la subjetividad invertida en el cuerpo, sembrando pistas sobre otros mundos posibles.

PALABRAS CLAVE: Ykamyabas; Amazonas; imaginario; femenino; mito

Citação recomendada:

AGUIAR, Renata. Ykamyabas: poéticas de um corpo-território. Revista Poiésis, Niterói, v. 22, n. 37, p. 41-62, jan./jun. 2021. [https://doi.org/10.22409/poiesis.v22i37.47234]

\section{(cc) BY-NC-ND}

Este documento é distribuído nos termos da licença Creative Commons Atribuição-NãoComercial 4.0 Internacional (CC-BY-NC) (c) 2021 Renata Aguiar

Renata Aguiar, Ykamyabas: poéticas de um corpo-território. 


\section{Ykamyabas: poéticas de um corpo-território}

\section{Apresentação}

Tenho no fundo dos olhos a imensidão do rio e a imensidão do ar, conheço florestas com verdes a perder de vista, minha terra é imensa, de horizontes continentais, nasci em Urucará, uma cidade ribeirinha do baixo Amazonas, cresci entre Rondônia e Pará, cercada por águas e florestas sem fim. Descobri viajando imensidões com as quais não estava familiarizada, paisagens tão distantes da minha, tão gigantescas, que não deixavam o olhar repousar sobre o horizonte; foram grandezas verticais, que me inspiraram "sonhos de voo" sussurrados por Bachelard. Em busca desses sonhos, percorri muitas cidades, vivi muitas vidas e usei umas tantas máscaras, no entanto, todos esses caminhos me levaram de volta para a Amazônia, profunda e misteriosa origem que relutante resolvi afinal pesquisar: é preciso ter de onde partir.
Não desejo aqui fazer um autorretrato ou narrar minha experiência particular, desejo investigar uma raiz profunda e ancestral de uma planta banhada pela lua, cartografar a geografia dos rios de um lugar entre o sonho e a memória, desejo navegar, fluir, seja olhando para o que reflete o espelho d'água ou mergulhando nas suas profundezas barrentas, nesse lugar de afeto onde recolho ou planto pistas de outros mundos possíveis.

Contaminada pelas narrativas das deusas Dina, Kali e Yacy que conheci nas andariIhagens do sul ao norte, do ocidente ao oriente, é no arquétipo da mulher selvagem que encontro terreno fértil para me fazer outras perguntas: Que corpoterritório emerge das poéticas do imaginário amazônico? Como as dimensões do sagrado apresentadas pelos mitos podem 
construir práticas e discursos de resistência? A Amazônia em seu imaginário próprio resiste à homogeneização globalizante e descoloniza corpos e mentes?

Foi pela fotografia que adentrei a Arte, esse coexistir de mundos que me permitiu circular em diversos ambientes. Meus modos de desvendar e falar sobre a fotografia enquanto arte e suas particularidades nunca deixaram de ser um olhar sobre o mundo vivenciado, um mundo no qual a Amazônia se faz presente por ser o ponto de encontro e de partida comum dos trabalhos desenvolvidos. Nesta perspectiva há uma significativa diferenciação entre os que elegem a região como tema de suas imagens e essa diferenciação se dá no como esse tema é apresentado.

Nas décadas finais do século $X X$ e início do século XXI, muitos outros fotógrafos foram, retornaram e continuam indo e vindo à procura de uma visibilidade e de uma visualidade amazônica conectora dos processos de construção da representação do lugar sem considerar esse lugar da forma dicotômica natureza $\mathrm{x}$ urbanidade. A partir desse olhar surge um discurso sobre as especificidades amazônicas e a sua apre- sentação não estereotipada pela fotografia, em contraposição à imagem amplamente aceita e benquista pela mídia, que trata a Amazônia como exótica, lugar sobre o qual se fala, mas que não fala de si.

A constância dos dualismos que fazem um corte entre natureza / cultura, corpo / mente, sujeito / objeto tem atribulado minhas formas de viver, pesquisar e fazer arte. Não foi sem alguma aflição que percorri a fronteira que separava (ou separa?!) minhas formas de fazer e teorizar arte das práticas culturais e artísticas que me traziam prazer e vitalidade. Tudo se tratava então de um jogo de máscaras. Pelo artifício da pose em justaposição ao relato oral de mulheres encarceradas, busquei criar uma noção de identidade no retrato fotográfico pesquisando o ambiente prisional feminino no Estado do Pará ${ }^{1}$, mas me parece hoje que o que fiz foi demostrar que o outro existe (SONTAG, 2004).

É Clarice (LISPECTOR, 1999) quem me fala, que apesar de anos de verdadeiro sucesso com a máscara, de repente essa máscara de guerra parte-se toda no rosto, lama seca; o rosto agora nu, maduro, 
sensível se dá a ver, é o lugar das fragilidades, das memórias. A busca por esse rosto é mergulho e superfície que pretendo percorrer, sobretudo, como água e como nau, num desejo de construção mais fluida de pesquisa-arte-vida. Percorrendo um acervo constituído por obras de arte, registros, performances, textos, hipertextos, processos ou vivências cotidianas do lugar de origem e afeto que podem revelar, narrar e recriar territorialidades, entre o mito e a fronteira (CASTRO, 2011) de uma Amazônia vivida e imaginada.

Assim, esse texto é um convite à floresta, às plantas, às águas e aos mistérios ocultos do inconsciente coletivo de um feminino submerso que, no entanto, ressurge como o corpo sagrado que não pode morrer e se apresenta nas narrativas ancestrais que em suas múltiplas aparições resistem nas Ykamyabas e seus mitos fundadores.

\section{A flor e a lua}

No início de todas as coisas, Tupã criou o universo, o céu e os seres luminosos; na terra caminhava carregando as chuvas, distribuindo raios e ecoando sua voz de trovão. Quando tudo era escuridão, criou Yacy, a guardiã da noite, criadora de todas as plantas, irmã gêmea e amante de Guaraci, o senhor do dia, pai de todos os animais.

Quando Guaracy - o sol - dormiu pela primeira vez, Yacy - a lua - surgiu solitária num céu sem estrelas. Ao despertar lentamente, Guaraci pôde vislumbrar sua irmã que sorria. Em nenhum mundo o sol havia presenciado tamanha beleza, mas à medida que se aproximava daquela que Ihe despertou fascínio, ardia e iluminava tudo que tocava. Yacy, que passara a noite acordada, adormecia e desaparecia. A lua, que também desejava o sol e entendia do amor e do tempo, escolheu se demorar um pouco mais, apenas quando estivesse plena e cheia, assim uma vez a cada ciclo eles poderiam se encontrar no alvorecer. Desse encontro de Yacy com Guaraci nasceu Rudá, o mensageiro, aquele que não conhece a luz ou a escuridão e desperta o amor nos seres viventes.

A senhora da madrugada era protetora dos amantes e a ela eram consagradas as Ykamyabas, guerreiras que habitavam o 
vale do lago do espelho da lua, o YacyUaruá. A pálida rainha do céu tinha por costume eleger entre as guerreiras a mais valente de cada geração para se tornar sua irmã-amante e brilhar com ela. A escolhida se tornava estrela para também iluminar as noites da floresta. Naiá era uma jovem guerreira que habitava o vale da lua; Rudá, sem avisar, surgiu no peito da pequena, que nas caçadas noturnas se distraía contemplando o luar. Yacy, por sua vez, não olhava para ela. Nas artes da guerra a pequena Naiá não se fazia, ainda assim todas as noites de lua cheia a jo-

\section{Lua, Lua, Luar}

\section{A lua sai de madrugada ao romper do sol}

Ela vai acompanhando a namorada que anda só $(2 X)^{2}$

\section{Ô lua, lua, luar, me leva contigo pra passear (2X) Refrão. (MESTRE LUCINDO) ${ }^{3}$}

A contradição que Naiá carregava era se apaixonar mais intensamente à medida que Yacy a ignorava. Nem sempre é fácil respirar na floresta e o rio barrento que

eram os olhos de Naiá não parava de trasbordar; enquanto a água corria, ela não comia nem bebia nada, fraca e confusa era fácil se perder mesmo em mata conhecida. Naiá estava perdida.

Yacy, que era deusa, não reparava no sofrimento da jovem e sem ainda lhe prestar demorada atenção, percebeu Naiá deitada à beira de um lago obscuro, profundo e intocado. Não havia vento nem bicho algum que turbasse a água e a lua resolveu darse a ver na superfície espelhada do lago. Naiá, vendo o espelho da lua, em delírio de paixão pensou que enfim sua amada Yacy havia atendido aos seus apelos e estava ali para levá-la. Retirou do corpo todos os adornos feitos de sementes, cipós e penas e enquanto seus olhos percorriam a lua do céu até a água, lentamente entrou no lago, perturbando o reflexo indiscernível da deusa de luz. Ao perceber que se tratava de um reflexo e que a amada deusa ainda não a correspondia, Naiá já cansada preferiu se afogar nas profundezas do espelho da lua a viver desejando aquela que jamais poderia tocar.

Yacy reconheceu o sacrifício da jovem e desgostosa de sua morte resolveu trans- 
formá-la em estrela. Naiá pesou sobre o fundo do lago por um momento e logo seu corpo pequeno e sem vida flutuou enquanto seus cabelos muito longos e grossos dançavam sob a superfície. Foi assim que a lua, observando pela primeira vez a beleza triste de sua amante intocada e morta, decidiu transformá-la na estrela das águas calmas, planta enorme, com foIhas redondas e uma flor estrelada que se abre durante a noite quando tocada pela luz de Yacy, pendendo suas raízes aquáticas, enquanto seu corpo flutua sobre a superfície espelhada.

\section{As Ykamyabas e o nascimento dos Muyrakytãs}

Contam as mais velhas histórias que no vale da lua, escondidas dos homens para além da serra Yacy-taperê, viviam guerreiras que não desejavam ou permitiam entre si a presença masculina. Elas eram conhecidas como Ykamyabas, as filhas da lua, caçadoras noturnas, hábeis com o arco e a flecha, versadas nos mistérios das plantas, irmãs e amantes de Yacy, as mães dos Muyrakytãs.
Uma vez por ano as guerreiras realizavam uma grande festa em nome de Yacy próxima a nascente do rio Yamundá (Nhamundá ou Jamundá), que corria para um vale onde se formava o lago do espelho da lua, o Yacy-uaruá. Elas dançavam, cantavam e tocavam seus instrumentos de pau e corda, riam e se divertiam umas com as outras. Pouco antes da meia-noite, quando a lua estava quase a pino, iam em procissão ao lago do espelho da lua, carregando nos ombros potes cheios de perfume feito com todas as ervas cheirosas do mato, que eram despejados nas águas escuras do lago espelhado onde se atiravam para um banho purificador.

À meia-noite, quando a lua se refletia na face lisa do lago, chegavam os Guaçaris, filhos do sol, guerreiros de lança, pescadores diurnos que sabiam os segredos dos animais. Eles eram especialmente convidados para a festividade, quando só então Ihes era permitido atravessar as fronteiras do território das mulheres. À luz do luar, tomados por Rudá, a festa continuava com músicas e danças que se intensificavam até o orgasmo geral. Após fazer amor com os Guaçaris, as Ykamyabas merguIhavam e traziam do fundo do lago um bar- 


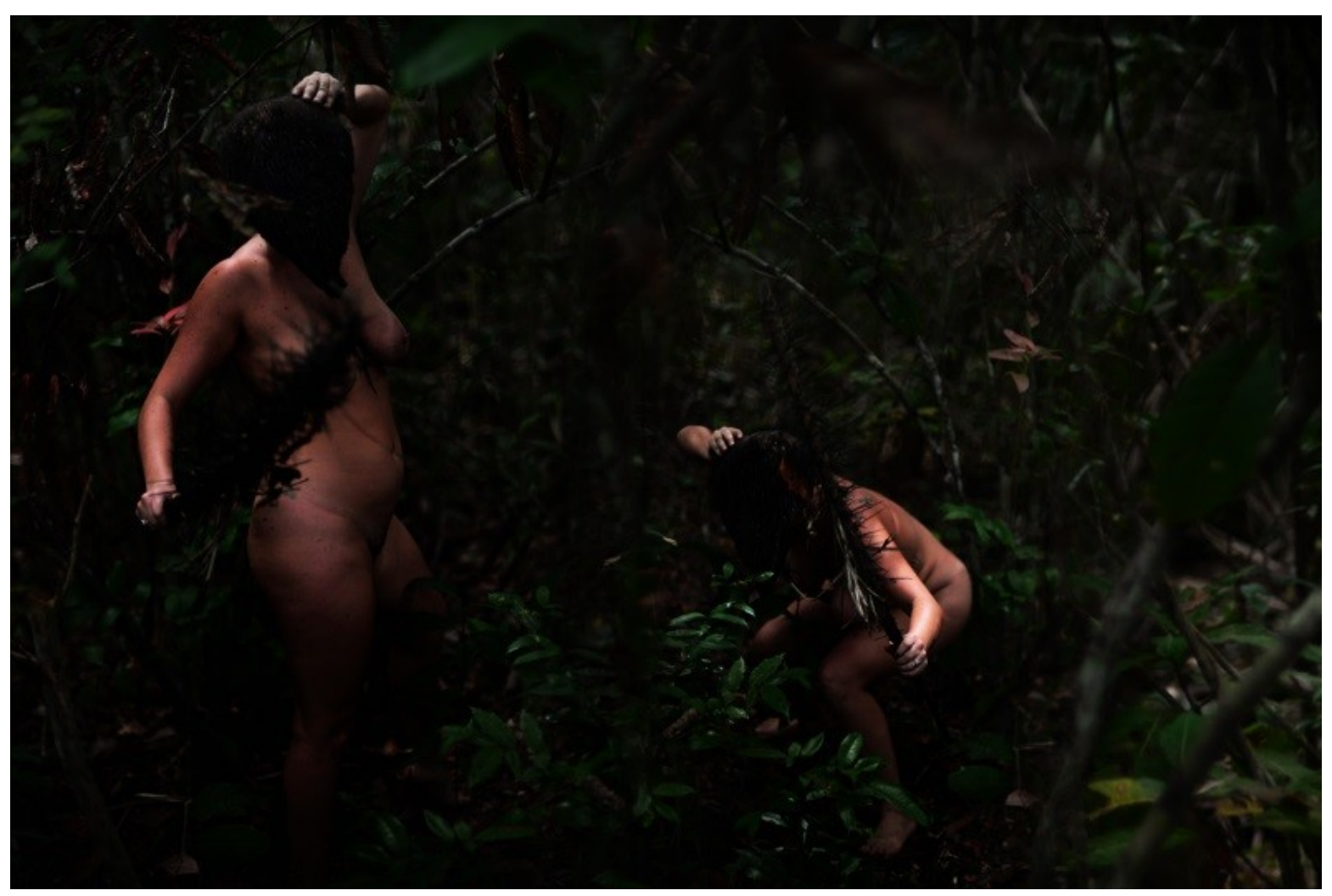

Fig. 1 - Renata Aguiar, Ykamyabas, 2019. Fotografia. (Fonte: Acervo pessoal da autora.) 
ro mole e verde, ao qual davam formas batraquianas: os Muyrakytãs, que endureciam ao ser retirados da água. Com esses objetos presenteavam seus amantes, que deveriam trazer o amuleto pendurado ao pescoço.

Hoje, em uma Amazônia múltipla, atingida por invasões e dominações, fragmentada por processos coloniais, projetos de 'desenvolvimento', baseados num modelo de exploração patriarcal monoteísta branco, de moral monogâmica em monoculturas de gênero, que vem devorando a terra e os seres, a Ykamyaba ( $r$ )existe na mulher que reaprendeu a lidar com a noite e com as ervas; ela é a bruxa, a guerreira, a mãe, a amante, é a filha da lua, irmã e amante do sol, irmã e amante das estrelas, é parente de todo ser vivente, é mãe das plantas, caçadora, ela canta, dança e ri alto, ela sabe girar e entende do tempo e dos ciclos, ela vive entre as mulheres, e os homens se aproximam quando convidados.

\section{Cair sem colapsar}

A busca pela representação do lugar desse que não é qualquer outro senão o que se me apresentou na cotidianidade, íntimo, particular e imenso, dilatado pela contiguidade das águas, ruas, becos e estradas -, se deu a partir dos caminhos que percorri "manipulando o aparelho, apalpando-o, olhando para dentro e através dele, a fim de descobrir sempre novas potencialidades" (FLUSSER, p.42, 1985), procurando perceber os cantos obscuros e pouco visitados do universo fotográfico, espaço debilmente iluminado pela chama midiática, tentando construir, para além do lugar comum do mercado e das padronizações das identidades e discursos homogeneizantes, uma fotografia que realize um universo fotográfico diverso e constitutivo de subjetivações não programadas (PAIM, 2012).

Assim, me lancei à experimentação entre o sonho e a memória presente nas histórias das Ykamyabas e seus mitos fundadores, que viviam na região do Rio Yamundá, afluente do Rio Amazonas, que desta forma foi denominado em referência àsmulheres guerreiras da mitologia grega. 


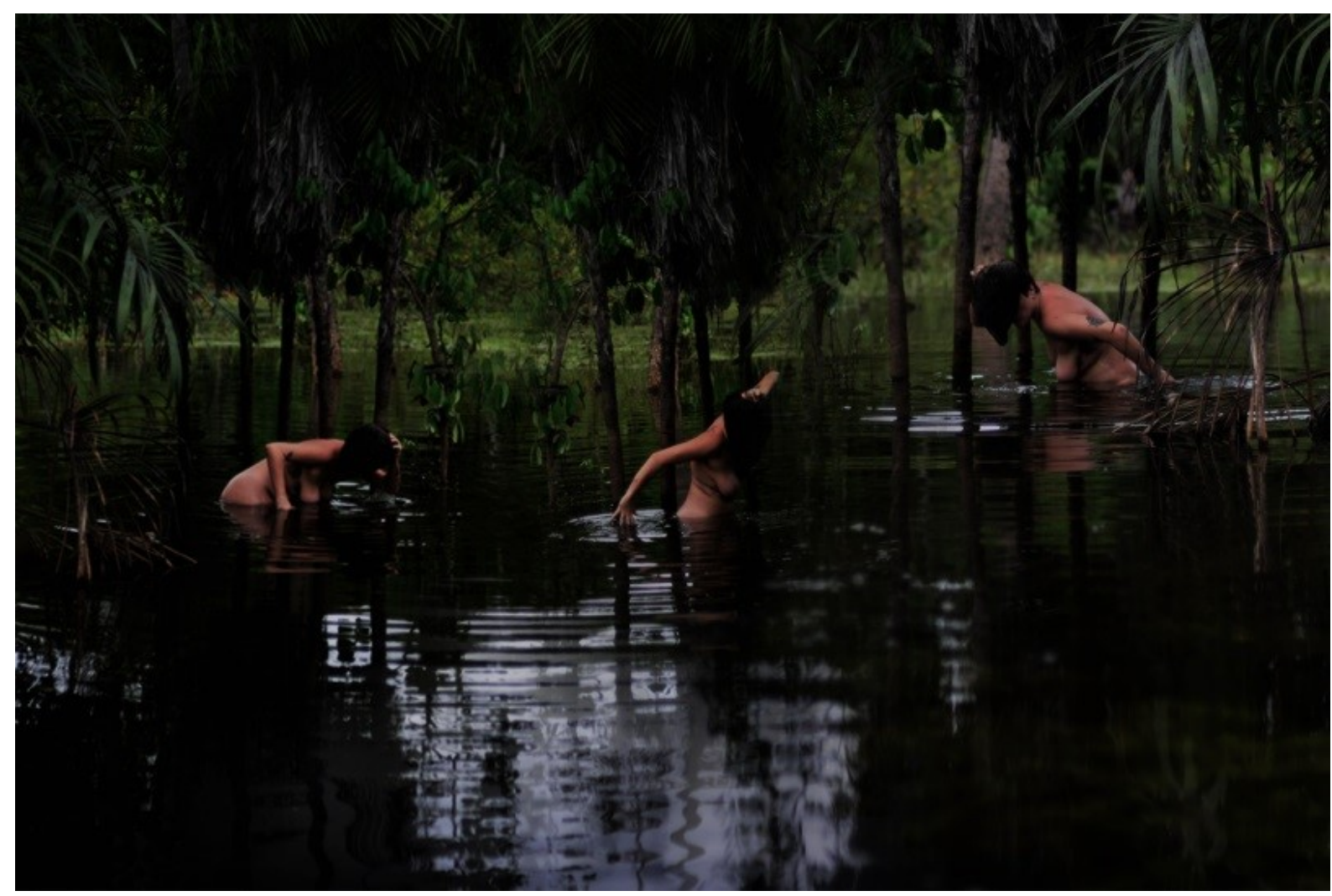

Fig. 2 - Renata Aguiar, O nascimento do Muyrakytã, 2019. Fotografia. (Fonte: Acervo pessoal da autora.) 
Foi Francisco de Orellana, que navegou o grande Rio de Quito até o Oceano Atlântico entre 1540 e 1542, quem primeiro descreveu em cartas à Europa (Espanha), o encontro com "índias" sem maridos que revidavam o combate, manejando com destreza o arco e a flecha. (COSTA; SILVA; ANGÉLICA, 2002).

Os registros escritos que comprovem a existência dessas guerreiras são escassos, no entanto, na Amazônia contemporânea são muitas as referências às mulheres que viviam sem maridos e guerreavam contra todos que tentassem invadir seu território. São pesquisas antropológicas ou artísticas que se baseiam ou reconstroem narrativas míticas, histórias passadas oralmente de geração em geração, raiz ancestral das diversas ficções que reconstroem o lugar de origem; como o romance "Terra de Icamiaba" de Abguar Bastos (1934), a animação para a televisão "Icamiabas" (TV Cultura Pará, 2012), a banda "Icamiabas" de rock feminista, o samba enredo "As Icamiabas" da Escola de Samba Arrastão de Cascadura (1996).

Esses mitos e histórias que falam de muIheres que existiam de forma livre ou di- versa do constructo de gênero socialmente imposto à mulher na sociedade ocidental, não só, mas principalmente cultura colonial, branca, patriarcal, judaico-cristã, binária, heteronormativa, são ecos de saberes ancestrais, que nos entregam hoje conhecimentos ancestrais que foram invisibilizados e quase destruídos. Histórias que chegam pela oralidade e estão presentes em quase todas as culturas, que podem nos oferecer um vislumbre da força da mulher selvagem e nos mostram caminhos para retornarmos a ela, toda vez que se faça necessário. (ESTER, 2014). Na Amazônia cresci ouvindo e sonhando com essas histórias, sentindo seu chamado voltei ao meu lugar de nascimento - Urucará - para percorrer rios e terras seguindo as pistas deixadas pelas Ykamyabas.

Em uma viagem, sobretudo familiar, imergi no cotidiano de uma cidade que tem como único acesso o rio e sem marcar encontro me deparei com mulheres que cantam, dançam e amam. Elas surgem nas matas, nas ruas, e se banham nos rios, vêm da roça de enxada na mão, com chapéu de palha e galocha, elas coletam cupuaçu, bacuri e debulham açaí, saem de 


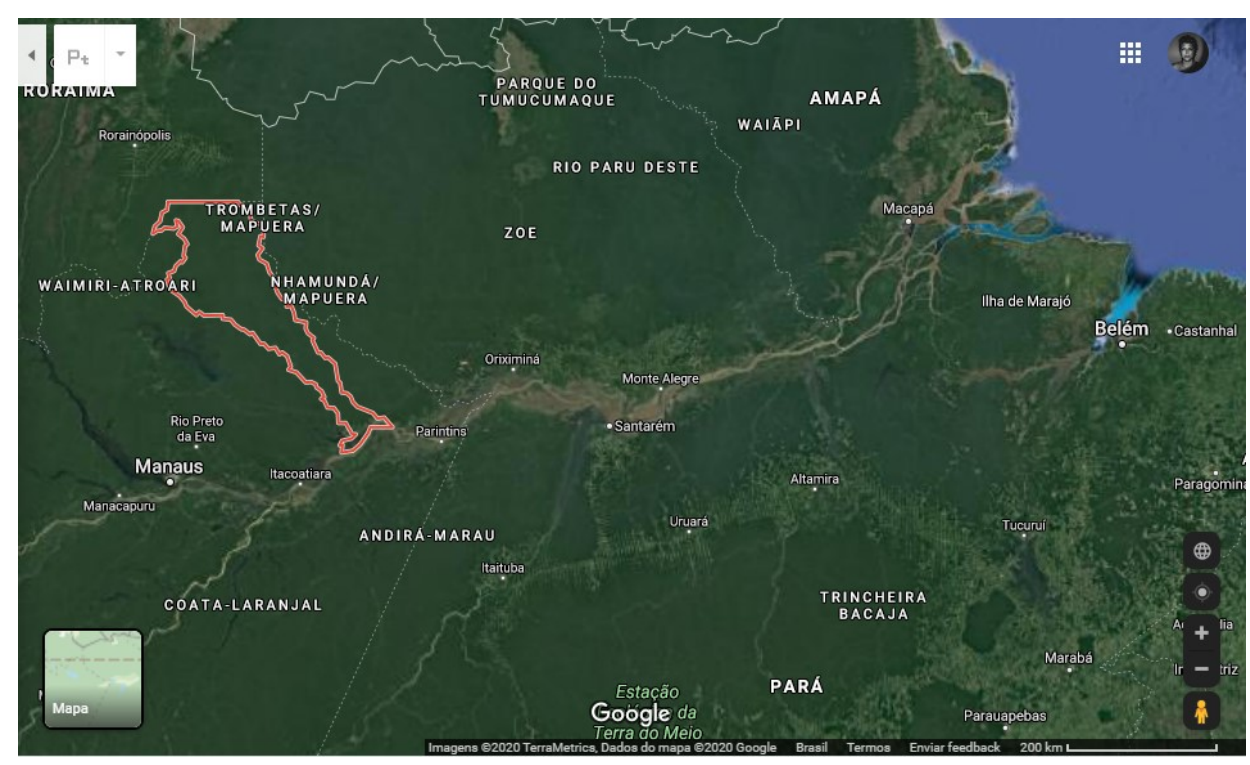

Fig. 3 - Google Maps. Localização do município de Urucará/AM, 2020. PrintScreen (Fonte: https://www.google.com.br/maps/ok) 
suas casas e levam os filhos à escola, andam de rabeta, remam o casco ou pilotam motos, são muitas e diversas, elas surgem nos sonhos e se apresentam na cotidianidade.

Sonhar é para mim um processo de olhar para trás e para frente ao mesmo tempo, reconhecendo e honrando minhas ancestrais enquanto vislumbro o que ainda não existe, as que virão depois de mim. Assim foi que com a ajuda da minha mãe adentrei a floresta e os igarapés para deixar fluir o arquétipo da mulher selvagem:

\section{Do ponto de vista da psicologia arquetípica [...] ela é a alma feminina. [...]. Ela estimula os humanos a continuarem a ser multilín- gues: fluentes no linguajar dos sonhos, da paixão, da poesia. Ela sussurra em sonhos no- turnos [...]. Ela é quem se enfurece diante da injustiça. Ela é a que gira como uma roda enorme. É a criadora dos ciclos. Éà procura dela que saímos de casa. É à procura dela que voltamos para casa. Ela é a raiz estrumada de todas as mulheres. Ela é tudo que nos man- tém vivas quando achamos que chegamos ao fim. Ela é a geradora de acordos e ideias pe- quenas e incipientes. Ela é a mente que nos concebe; nós somos os seus pensamentos. (ESTER, 2014, p. 37)}

As ciências modernas, desde muito encarceraram o feminino pelo pensamento dualista que o fundamenta. Foi assim que vimos o ser mulher e a feminilidade serem construídas e perspectivadas "como uma metade dos seres livres" (ARISTÓTELES, 2004, cap. IV, p. 17), sendo concebido como uma forma de vida humana inferior por sua matéria corpórea associada à animalidade tanto na cultura ocidental como nas disciplinas humanistas.

Com o surgimento do "homem da razão" vemos a produção do dualismo cultu$\mathrm{ra} /$ natureza nas relações sexualizadas homem/mulher com uma patente dominação masculina sobre o ser "menos humano", uma categoria entre o humano e o não humano que definiu o constructo do ser mulher, surgido de uma racionalização do mimetismo biológico que pretendia comprovar como "natural" a relação do corpo feminino com a natureza. Assim o cogito cartesiano "penso, logo existo" jogou definitivamente o corpo para fora das questões filosóficas, pois inserido na ordem de leis da natureza, pertencente ao mundo do sensível e, portanto fonte de confusão da razão e obscurecimento do pensamento. 
O pensamento cartesiano, método filosófico fundamental do saber moderno, legitimou a cisão corpo/mente, dando a partir da objetividade e racionalidade contribuição basal para o homem se pensar como sujeito soberano, subjetividade autônoma e racional diante do mundo objetificado de uma natureza que existe para fora dele e que em geral tem o estatuto do feminino. Assim também o empirismo prático de Francis Bacon, que em certa medida é aliado da teoria cartesiana, define a natureza a partir de uma correlação do feminino como um modelo mecânico uniforme que metáfora que Bacon (2012) constrói em seu texto "O nascimento do tempo masculino" é de um estupro, assim "o poder da natureza é tomado à força para que seus mistérios sejam devassados pelo cientista", como afirma Rita Therezinha (SCHMIDT, 2012, p. 236).

Desta forma, empirismo científico e racionalismo filosófico corroboram e mutuamente constroem a ideia dos dualismos cultura/natureza, mente/corpo e sujeito/objeto, hierarquizados pelo ideal de uma mente que transcende o corpo sexuado, mas que é objetivamente masculino,

pois seu lugar de diferença se dá no feminino, constituído por sua corporeidade material, comumente relacionada aos animais e reduzidas a máquinas reprodutivas.

Apesar das variáveis que incidem sobre o percurso histórico na construção do pensamento ocidental, os dualismos que apartam corpo/mente, cultura/natureza e se reproduzem no paradigma binário homem/mulher, perpetuam uma metáfora que exclui da razão a natureza e, portanto o feminino como sua representação, das práticas hegemônicas do saber/poder ocidental, e desvalorizam a natureza e todas as formas de existência "não humana", já que o humano racional objetivo é abalizado pelo masculino. Assim este mascaramento falocentrista fabrica uma verdade única, como demonstrado por Judith Butler ao examinar a manipulação epistêmico-discursiva na construção do ser mulher como "fato natural" pelo sistema ontológico que produz o natural como se fosse o efeito de um real original e inevitável (BUTLER, 2003).

Numa leitura crítica dessa história percebo as similaridades entre os fenômenos que 
conectam o desenvolvimento do racionalismo e conhecimento científico da natureza, pautado na dominação do feminino/natureza, com os processos de expansão colonialista da Europa que levaram à exploração e conquista de outras gentes consideradas incivilizadas, selvagens: os "quase humanos". Um modelo exploratório que nos colocou em uma crise ecológica de proporções planetárias, numa lógica de produção e consumo que exaure os recursos terrestres.

\section{Talvez estejamos muito condicionados a uma ideia de ser humano e a um tipo de existên- cia. Se a gente desestabilizar esse padrão, talvez nossa mente sofra uma espécie de rup- tura, como se caíssemos num abismo. Quem disse que a gente não pode cair? (KRENAK, 2019, p. 57)}

Essa queda que me interessa. A vertigem do giro epistemológico dos eixos até então estabelecidos na minha prática de pesquisa em artes, o abismo que se apresenta como possibilidade de deslocamento. É assim que volto minha atenção aos mitos amazônicos e suas apresentações do feminino e dos seres que são entidades muitas vezes quase humanas, onde a frontei- ra dual que separa humanos e não humanos, natureza e cultura, não foram completamente estabelecidas. Apesar das investidas colonizadoras e colonizantes dos corpos-mentes, a Amazônia em seu imaginário próprio resiste à homogeneização das identidades e entrega no hoje histórias e mitos que estabelecem uma outra forma de ser e estar em relação com o mundo.

Até então, como mulher branca e artista acadêmica, estive imersa na investigação da fotografia a partir de seu entendimento como imagem técnica, que é a imagem produzida por um aparelho e este por sua vez é texto científico aplicado. Flusser (1985) diz que as imagens técnicas pretendiam ser janelas para o mundo, mas ao interporem-se entre as pessoas e o mundo passaram a ser biombos; no entanto, e aí mora a contradição, essa perspectiva é um subproduto cartesiano, da noção de interno e externo - o suposto representacionismo da imagem se baseia na ideia de que é possível observar exteriormente os fenômenos -. No entanto:

\section{[...] 0 "conhecedor" não permanece na abso- luta externalidade em relação ao mundo na-}


tural investigado — não há tal ponto de observação exterior. (BARAD, 2017, p. 31)

Fotografar é fazer surgir outro mundo, articulando cenas e reconstruindo realidades, mas é o conhecimento permeado pela realidade do mito, das narrativas orais e das histórias que nos quiseram fazer esquecer, "do lugar onde são possíveis as visões e os sonhos. Um outro lugar onde a gente pode habitar além dessa terra dura: o lugar do sonho" (KRENAK, p.65, 2019) que intuo ser o lugar da arte, do fazer-se artista, um lugar onde tenho cada vez

forma expressa e performativa a materialidade mesma da minha existência, uma existência em tudo marcada pelas relações dadas não só pela subjetividade, mas investida de corpo, imbricadas em uma "dupla sensação". Assim:

\section{[...] a experiência subjetiva do corpo como forma sensivel sublinha a indissociabilidade dos espaços corporais e psíquicos, desfazen- do a oposição entre 0 interior e 0 exterior, 0 dentro e o fora. É precisamente essa interre- lação que torna possível a inscrição do corpo e da subjetividade no eixo da diferença e do desejo, o qual se reveste de implicações polí-}

ticas, uma vez que a diferença sexual não é apenas uma abstração, mas se materializa em um corpo, o corpo é de uma mulher e esse corpo é matéria da subjetividade, é o que Ihe dá substância e existência. (SCHMIDT, 2012, p. 247)

Para a construção de um mundo ampliado nas possibilidades de uma realidade constituída em rede aberta e constante movimento, onde para além de sujeito isolado ou preso a dicotomia corpo/mente, cultu$\mathrm{ra}$ /natureza, me percebo imbricada em um coletivo que se auto-organiza na coletividade. Assim, vontades, desejos, decepções e lutas expressas em ações e atitude não são configurações puramente individuais, mas da abrangência política, ecológica e social que me compõe. Aqui construí um mapa, que se assemelha à cartografia de rio, disparo efetuado pelo espinho da pupunheira, frágil unidade de proteção de uma árvore de igapó, que tenho usado durante anos como agulha na construção de câmaras obscuras e câmeras pinhole, aparatos técnicos, próteses que modificam o mundo a minha volta. Esse pequeno pedaço de madeira perspectivado por um coletivo de pesquisadores, meus colegas do Programa de Pós- 
Graduação em Artes Visuais da Escola de Belas Artes da Universidade Federal do Rio de Janeiro, me deu a ver as múltiplas relações das diversas práticas de arte e vida nas quais tenho me engajado.

O mapa trouxe para a superfície do plano os múltiplos fazeres e seus desdobramentos psíquicos com os quais tenho me empenhado e me deu a ver possíveis conexões, despertando a vontade de integrar essas esferas da existência que permeiam minhas formas de fazer e pensar arte. Foi assim que decidi que na exposição "Contingências", na Galeria Apis na cidade do Rio de Janeiro, em novembro de 2019, apresentaria junto ao trabalho "As Ykamyabas" e "O nascimento dos Muyrakytãs"; faria também uma performance de carimbó, o som que rege a Amazônia e embala minhas noites de sonhos e festas de floresta e rio. Assim convidei o carimbozeiro e pernalta paraense, produtor do bloco carnavalesco de carimbó "Vai Tomar na Cuia", Andrey Alves, e o do carimbozeiro do grupo "Tamaruteua: carimbó é vida" e Prof. Dr. Luizan Pinheiro, que então realizava estágio pósdoutoral na Universidade Federal Fluminense e que foi meu professor de Metodo- logia da Pesquisa no Mestrado do Programa de Pós Graduação em Artes da UFPA em 2011, para tocarmos juntos, dando um salve às Ykamyabas, à sua memória e resistência.

Entretanto, como afirma Susan Sontag, a resistência sozinha não tem valor, "é o 'conteúdo' da resistência que determina o seu mérito, a sua necessidade moral" (2008, p. 184). Essas poéticas políticas, quando instauram no campo imaginalimaginário? a existência que há muito tempo estava oculta ou suprimida da selvagem uma força feminina, marginal, indomada, livre - podem "resselvagizar" as relações entre humanos e não humanos, cindidas pelas dualidades e conseguinte subjugação da "natureza" e nos reintegrar ao mundo, antes que este se desintegre, pois mesmo que sejamos ainda geneticamente selvagens, nossos corpos/mentes são há muito domesticados: 


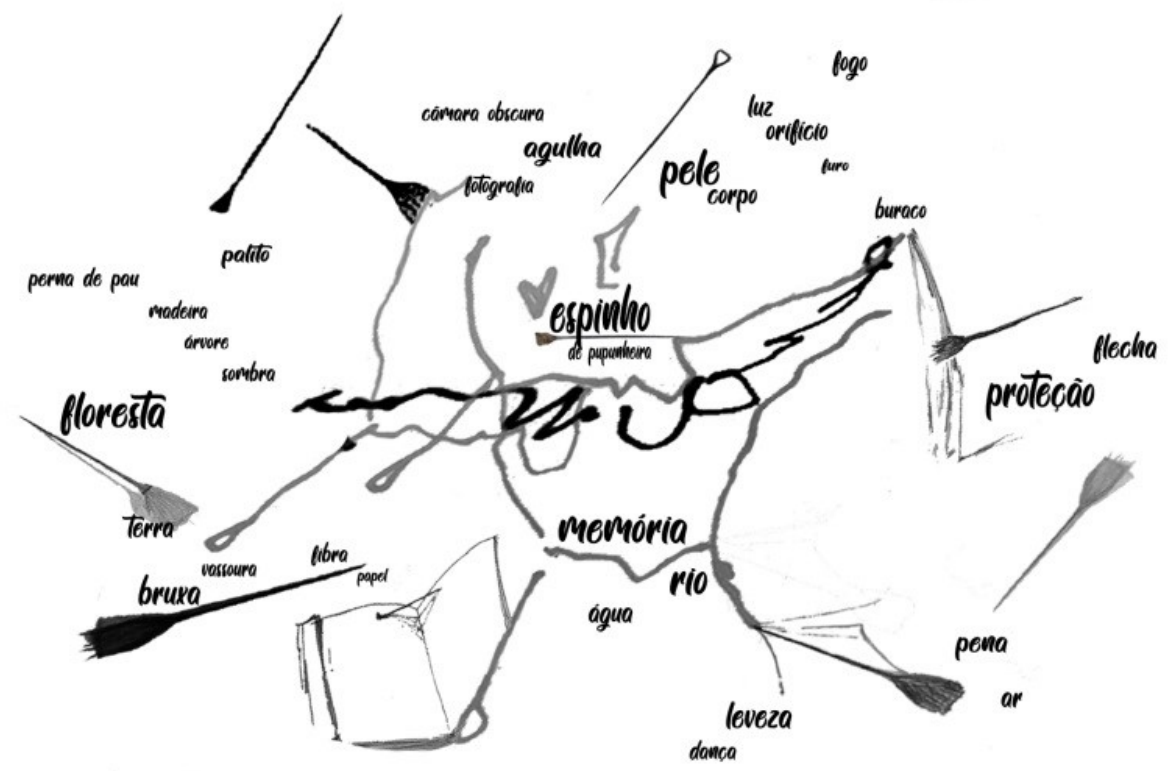

Fig. 4 - Renata Aguiar. Mapa espinho, 2019. Técnica mista. Acervo pessoal. 


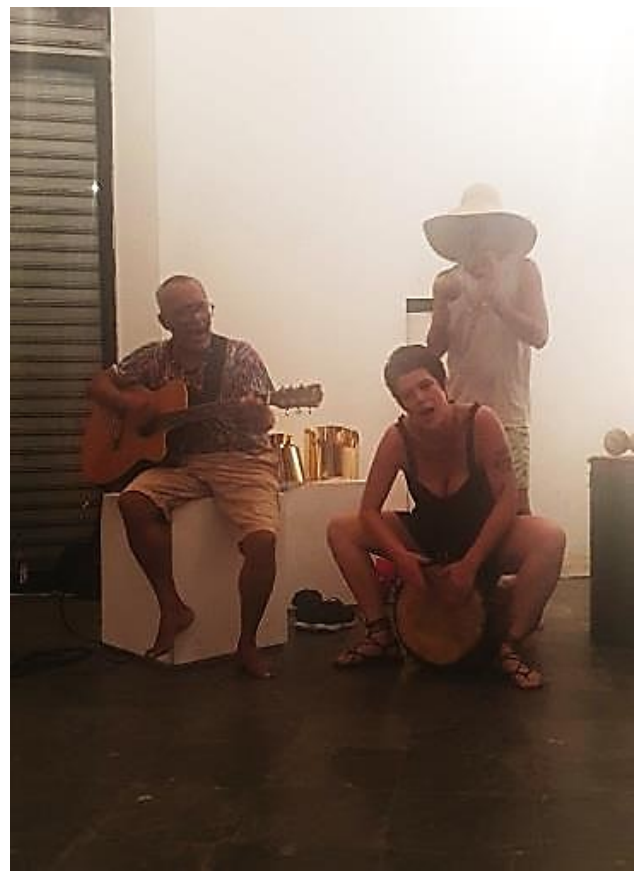

Fig. 5 - Autor desconhecido. Registro da performance de Carimbó, 2019. Acervo pessoal. 
Com a educação, fomos subjugados psicologicamente, com a tecnologia, nossos sentidos foram anestesiados e a especialização nos despiu de nossas habilidades de sobrevivência mais básicas. Resselvagizar requer, portanto, descolonizar a mente, afiar os sentidos e readquirir habilidades. (WORKMAN, 2015, p. 5)

Assim, ao contar e recontar as histórias das Ykamyabas e seus modos de vida, percebo a presença da mulher selvagem, que desconstrói as diversas lógicas disciplinadoras dos corpos femininos e das práticas de exploração da "natureza" - seja nas relações não monogâmicas, afetos e sexualidades fluídas, forças masculinas e femininas não hierarquizada, parentesco com corpos celestes e todos os seres viventes e relações de territorialidade sagrada - e reafirmam a potência descolonizadora do imaginário amazônico.

\section{Inconclusões}

Entendo que arte constrói discursos que são difundidos, valorados e apropriados pela sociedade, principalmente pelas mudanças que a revolução industrial e a reprodutibilidade técnica do início do século
XX trouxeram para forma como artistas, fotógrafas e os meios de comunicação lidam com obras e imagens fotográficas. Percebo mais recentemente que para além dos discursos, a arte instaura realidades e funda mundos, performando práticas e ações que agenciam relações. Como as fronteiras entre essas áreas tem se tornado cada vez mais imprecisas e fugidias, o método cartográfico se torna importante referente para abordar nesta pesquisa as relações, enfrentamentos e cruzamentos entre forças, agenciamentos, jogos de verdades, objetivação e subjetivação, produções e estetizações de si mesmo e do outro, práticas de resistência e liberdade, a pesquisa em arte a partir da perspectiva arte-vida-pesquisadora.

Dessa forma, construo caminhos e mapas do imaginário amazônico contemporâneo em sonho, pista, vestígio e devir, num acervo constituído por obras de arte, registros, performances, imagens, textos, hipertextos, processos ou vivências cotidianas que instauram, narram e recriam a realidade das pessoas e dos lugares onde nos inserimos, agenciando territorialidades a partir de corpos em constante movimento. Um percurso sobre saber cair sem colapsar, 
experienciar as mudanças radicais que o pensamento feminista, queer e decolonial têm proposto. Vivenciar os ciclos de morte e vida, noite e dia, que dizem respeito às constantes transformações que permeiam tudo o que há, é uma trilha no desejo de as pistas ancestrais que resistiram à devoração e gradual desencantamento do mundo, pois se vamos cair, que seja uma queda linda, uma queda potente e que estejamos de olhos bem abertos, conscientes da vertigem que é o mergulho no ar.

\section{Notas}

${ }^{1}$ Conceito desenvolvido na minha dissertação de mestrado Identidades Submersas: mulheres presas para a Universidade Federal do Pará, onde pesquisei as relações presentes entre fotografia e identidade a partir das histórias de vida e relatos orais das internas do Centro de Reeducação Feminino - CRF, então único presídio feminino do estado do Pará. Trabalho disponível em https://docplayer.com.br/110019859Universidade-federal-do-para-intituto-de-ciencias-daarte-programa-de-pos-graduacao-em-artes-renataaguiar-rodrigues.html.

${ }^{2}$ Esse trecho da música é controverso, já que há outras versões nas quais se fala "Ela vai acompanhando o namorado, que é o Sol".

3 Lucindo Rebelo da Costa, ou Mestre Lucindo, do município de Marapanim, no litoral paraense. Natureza e romantismo eram duas constantes na obra do pescador e Mestre de Carimbó, que em 2008 completaria seu centenário.

\section{Referências}

ARISTÓTELES. Política. Trad. Torrieri Guimarães. São Paulo: Martin Claret, 2004.

BACHELARD, Gaston. A água e os sonhos - Ensaio sobre a imaginação da matéria. Tradução de Antônio de Pádua Danesi. São Paulo: Martins Fontes, 2002.

BACHELARD, Gaston. O ar e os sonhos Ensaio sobre a imaginação do movimento. Tradução de Antônio de Pádua Danesi. São Paulo: Martins Fontes, 2001.

BACON, Francis. Temporis Masculus Par-

tus. Disponível em http://www.archive. org/stream/worksfrancisbaco07bacoiala\#p age/n11/mode/2up. Acesso em $15 / 1 / 2018$.

BARAD, Karen. Performatividade póshumanista: para entender como a matéria chega à matéria. 2003. Tradução de Thereza Rocha. Revista Vazantes, Fortaleza, v. 1, n. 1, p. 7-34, 2017.

BUTLER, Judith. Problemas de gênero. Rio de Janeiro: Civilização Brasileira, 2003.

CASTRO, Fabio Fonseca de. Entre o Mito e a Fronteira: estudo sobre a figuração da Amazônia na produção artística contemporânea de Belém. Belém: Edição do Autos, 2011. 
COESSENS, Kathleen, Anne Douglas, and Darla Crispin (2009) The Artistic Turn: A Manifesto, Orpheus Research Centre in Music Series 1. Leuven: Leuven University Press, 2009.

COSTA, Marcondes Lima da; SILVA, Anna Cristina Resque Lopes da; ANGÉLICA, Romulo Simões. Muyrakytã ou muiraquitãn, um talismã arqueológico em jade procedente da Amazônia: aspectos físicos, mineralogia, composição química e sua importância etnogeológica. ACTA Amazônica, Manaus, v. 32, n. 3, p. 467490 jun./set. 2002. Disponível em http://www.scielo.br/pdf/aa/v32n3/18094392-aa-32-3-0431.pdf. Acesso em $10 / 5 / 2019$.

ESTER, Clarissa Pinkola. Mulheres que correm com lobos: mitos e histórias do arquétipo da mulher selvagem. Rio de Janeiro: Rocco, 2014.

FILHO, Kleber Prado e TETIA, Marcela Montalvão. Cartografia como método para as ciências humanas e sociais. Barbarói, Santa Cruz do Sul, n. 38, p. 45-59, jan./jun. 2013. Disponível em https://online.unisc.br/seer/index.php/bar baroi/article/view/2471/2743. Acesso em $5 / 8 / 2018$.

FLUSSER, Vilém. Filosofia da Caixa Preta: ensaios para uma futura filosofia da fotografia. São Paulo: Hucitec, 1985.
KRENAK, Ailton. Ideias para adiar o fim do mundo. São Paulo: Companhia das Letras, 2019.

LISPECTOR, Clarice. A Descoberta do Mundo. Rio de Janeiro: Rocco, 1999.

PAIM, Claudia. Táticas de Artistas na América Latina: coletivos, iniciativas coletivas e espaços autogestionados. Porto Alegre: Panorama Crítico, 2012.

SANTAELlA, Lucia. Por que as comunicações e as artes estão convergindo? São Paulo: Paulus, 2005.

SCHMIDT, Rita Terezinha. Para além do dualismo natureza/cultura: ficções do corpo feminino. Organon, Revista da Faculdade de Filosofia da Universidade Federal do Rio Grande do Sul, Porto Alegre, v. 27. n. 52, p. 233-261, 2012.

SONTAG, Susan. Ao mesmo tempo. Tradução de David Rieff. São Paulo: Companhia das Letras, 2008.

SONTAG, Susan. Sobre Fotografia. São Paulo: Companhia das Letras, 2004.

WORKMAN, Dion. Uma Introdução ao pensar como floresta. Tradução de Jorge Mena Barreto. Disponível em http://files.cargocollective.com/556035/ FLORESTA.pdf. Acesso em 5/8/2019. 